\title{
ISLAM DAN PENDIDIKAN KARAKTER DALAM FRAMING MEDIA ONLINE
}

\author{
Mariani Amri \\ Program Studi Ilmu Komunikasi, President University \\ Alamat: Jababeka Education Park, Jalan Ki Hajar Dewantara RT. 2/RW. 4 \\ Mekarmukti, Cikarang Utara, Bekasi, Jawa Barat 17550 \\ Email: marinathar1@gmail.com \\ DOI: $10.29313 /$ tjpi.v7i1.3802 \\ Accepted: June 6th, 2018. Approved: July 16th, 2018. Published: July 16th, 2018
}

\begin{abstract}
This article focuses on news about Islam and character education in the online media tribunnews.com. Online media of choice in accessing information because of the speed and simplicity over an internet connection. Media has the ability to construct and frame the reality that Islam and character education has the potential to be constructed and framed by the online media in the form of news. This study aims to determine how online media framing and constructing reality tribunnews.com news about Islam and character education. This study uses qualitative research methods to the analysis of framing by Robert Entman focusing on problem identification, causal interpretation, moral evaluation, and treatment recommendation. The findings show that tribunnews.com in Islam and character education framing tend to show support and appreciation of government and various circles to the development and strengthening of Islamic character education. Some paths that can be taken in the development of character education that is through education in schools, families and communities so that the necessary cooperation and participation of parents and teachers. Islamic character education is the key factor in avoiding the next generation in their negative behavior face the challenges of globalization and advances in information technology.
\end{abstract}

Keywords: Islamic, Character Education, Framing, and Online Media.

\begin{abstract}
ABSTRAK
Artikel ini fokus pada pemberitaan mengenai Islam dan pendidikan karakter di media online tribunnews.com. Media online menjadi pilihan dalam mengakses informasi karena faketor kecepatan dan kemudahannya melalui koneksi internet. Media memiliki kemampuan untuk mengonstruksi dan membingkai realitas yang ada sehingga Islam dan pendidikan karaketer memiliki potensi untuk dikonstruksi dan dibingkai oleh media online dalam bentuk berita. Penelitian ini bertujuan untuk mengetahui bagaimana media online tribunnews.com membingkai dan mengonstruksi realitas berita mengenai Islam dan pendidikan karakter. Penelitian ini menggunakan metode penelitian kualitatif dengan analisis framing oleh Robert Entman yang berfokus pada problem identification, causal interpretation, moral evaluation, dan treatment recommendation. Temuan menunjukkan bahwa tribunnews.com dalam membingkai Islam dan pendidikan karakter cenderung menunjukean dukungan dan apresiasi pemerintah dan berbagai kalangan terhadap pengembangan dan penguatan pendidikan karakter yang islami. Beberapa jalur yang bisa ditempuh dalam rangka pembangunan pendidikan karakter yaitu melalui jalur pendidikan di sekolah-sekolab, keluarga, dan masyarakat sehingga diperlukan kerja sama dan peran serta orang tua dan guru. Pendidikan karakter yang Islami menjadi kunci utama dalam menghindarkan generasi bangsa dalam perilaku yang negatif menghadapi tantangan di era globalisasi dan kemajuan teknologi informasi.
\end{abstract}

Kata Kunci: Islam, Pendidikan Karakter, Framing, dan Media Online. 


\section{PENDAHULUAN}

Kebutuhan akan informasi yang dapat diakses melalui media menjadi sesuatu hal yang sangat penting. Informasi-informasi yang menarik, akurat, aktual, dan kecepatan menjadi sebuah tuntutan bagi masyarakat saat ini. Salah satu pilihan dalam mengakses informasi tersebut adalah media online. Kemajuan teknologi informasi memudahkan masyarakat memanfaatkan media online melalui koneksi internet.

Pada tahun 1997, internet mulai diperlakukan sebagai paradigma baru. Dengan internet, terdapat kemungkinan yang makin luas untuk belajar, baik secara formal maupun informal. Muncul klaim bahwa World Wide Web, jika aksesnya terbuka, akan melayani banyak hal seperti 'university without walls', bahkan akan menghapus ruang kelas. William Winston dalam bukunya Twilight of Sovereignty (1995) berpendapat bahwa melalui konvergensi teknologi kita dapat mengembara menuju 'lebih banyak kebebasan', 'lebih banyak kekuatan di pihak rakyat', dan lebih banyak kerjasama internasional (Briggs \& Peter, 2006).

Beberapa aplikasi internet misalnya berita online merupakan perluasan dari jurnalisme surat kabar. Berita online semakin berkembang ke arah yang baru dengan kemampuan baru atas konten dan bentuk. Misalnya, masyarakat dapat berperan sebagai jurnalis. Internet sebagai media memiliki ciriciri utama yaitu teknologi berbasis komputer, potensi interaktif, fungsi publik dan privat, peraturan yang tidak ketat, kesalingterhubungan, ada dimanamana/tidak tergantung lokasi, dapat diakses individu sebagai komunikator, media komunikasi massa dan pribadi (McQuail, 2011).

Media online menyediakan ragam informasi yang menjadi konsumsi khalayak termasuk pemberitaan mengenai Islam dan pendidikan karakter. Islam dan pendidikan karakter adalah dua hal yang tidak dapat dipisahkan. Kedua hal ini akan menunjang banyak aspek dalam kehidupan mulai dari ruang lingkup terkecil yaitu keluarga hingga kehidupan bermasyarakat, berbangsa dan bernegara.

Pada saat media massa menggunakan Islam dan pendidikan karakter sebagai objek pemberitaan dalam proses pemberitaan, informasi mengenai Islam dan pendidikan karakter akan menyebar dengan cepat dan terkonstruksi sebagai pengetahuan di masyarakat. Proses yang terjadi melalui tiga tahap yaitu eksternalisasi, objektivasi, dan internalisasi. Proses eksternalisasi terhadap objek dan proses Islam dan pendidikan karakter terjadi dengan cepat sebagai akibat dari penyesuaian diri yang sangat cepat dari masyarakat yang terbuka untuk menerima informasi baru melalui media massa termasuk informasi Islam dan pendidikan karakter. Proses objektivasi, masyarakat informasi yang terbuka dengan pola-pola interaksi yang terbuka pula akan memudahkan terciptanya proses intersubjektif yang dilembagakan, sehingga informasi Islam dan pendidikan karakter yang disampaikan oleh media massa, akan dengan mudah mengalami proses institusionalisasi di masyarakat sehingga seakan informasi Islam dan pendidikan karakter telah menjadi bagian yang tidak terpisahkan dari kehidupan masyarakat itu sendiri hingga akan menstruktur dalam kehidupan masyarakat pada umumnya. Proses internalisasi dimana masyarakat yang sudah terobjektivasi dengan Islam dan pendidikan karakter akan mengidentikasikan dirinya sebagai bagian fungsional dari informasi itu sendiri sehingga masyarakat akan menjadi terbiasa dengan Islam dan pendidikan karakter (Bungin, 2006).

Pendidikan merupakan hal yang sangat penting untuk dicermati secara seksama baik yang bersifat akademis maupun non akademis. Prestasi akademis yang tinggi sebaiknya dibarengi dengan prestasi non akademis yang baik termasuk akhlak dan perilaku yang mulia. Pendidikan mampu menjadi kunci utama pembentukan karakter yang Islami. Penguatan karakter 
adalah tanggung jawab dan perlu kerja sama semua pihak, baik keluarga, sekolah, pemerintah, dan semua elemen terkait. Jika setiap elemen bisa menjalankan peran masing-masing dengan niat yang tulus dengan penuh dedikasi dan tanggung jawab, pendidikan karakter yang islami bisa terwujud.

Hakikat pendidikan tidak hanya sebatas transfer of knowledge akan tetapi juga transfer of values. Hal tersebut dilakukan untuk membangun karakter yang berkepribadian mulia yang didasari nilai-nilai agama sebagai pondasi/dasar utama. Dengan demikian, mampu melahirkan jiwa karakter yang kuat, terpeliharanya generasi penerus bangsa yang memiliki kepribadian religius, berakhlaqul karimah, berpikir kritis, inovatif, menguasai ilmu pengetahuan dan teknologi (IPTEK) serta di landasi dengan iman dan takwa (IMTAK) yang tinggi. Tujuan utama pendidikan karakter menurut Islam adalah membentuk kepribadian yang memiliki etika, dan rasa berbudaya yang baik serta mewujudkannya dalam kehidupan seharihari (Musrifah, 2016).

Tantangan dan permasalahan seiring waktu semakin komplit bagi generasi penerus bangsa di era globalisasi dan era digital. Islam dan pendidikan karakter menjadi kunci untuk menghindari pengaruh, tindakan dan perilaku negatif dalam bermasyarakat, berbangsa, dan bernegara. Karakter dalam Kamus Besar Bahasa Indonesia (KBBI, 2012) diartikan sebagai jiwa, kepribadian, budi pekerti, perilaku, sifat, tabiat, dan watak. Karakter yang dimiliki seseorang berbeda dengan yang lainnya. Orang yang memiliki pendidikan karakter yang Islami berarti orang yang memiliki kepribadian dengan menjunjung tinggi nilai - nilai Islam yang bisa diraih salah satunya melalui jalur pendidikan sebagai sarana pembentukan karakter yang Islami melalui keluarga, sekolah, dan masyarakat.

Karakter identik dengan akhlak, moral, dan etika. Maka dalam persfektif Islam, karakter atau akhlak mulia merupakan suatu hasil dari proses penerapan syariat (ibadah dan muamalah) yang dilandasi oleh kondisi akidah yang kokoh dan bersandar pada al- Qur'an dan al-Sunah (Hadits). Nilainilai yang terkandung dalam pendidikan berkarakter yang dirumuskan oleh Kemendiknas (2010) meliputi delapan belas nilai yaitu religius, jujur, toleransi, disiplin, kerja keras, kreatif, mandiri, demokratis, rasa ingin tahu, semangat kebangsaan, cinta tanah air, menghargai prestasi (Musrifah, 2016).

Media online memainkan peranan yang penting dalam konstruksi pemahaman Islam dan pendidikan karakter. Media online yang berbeda mampu memberikan pemahaman yang berbeda pula mengenai Islam dan pendidikan karakter. Media memiliki kemampuan untuk mengonstruksi dan membingkai realitas yang ada. Islam dan pendidikan karakter memiliki potensi untuk dikonstruksi dan dibingkai secara berbeda oleh media online dalam bentuk berita.

Konstruksi sosial media massa (the social construction of mass media) memiliki pengaruh yang sangat kuat dalam mengonstruksi agenda pemberitaan media di masyarakat sehingga agenda tersebut menjadi konstruksi pengetahuan di masyarakat pada umumnya. Kekuatan konstruksi sosial media massa terletak pada kekuatan media massa sebagai media penyebaran informasi yang sangat cepat, luas, serentak, dan dapat mengonstruksi citra yang amat berkesan terhadap objek pemberitaan di masyarakat (Bungin, 2006).

Media memiliki fungsi penting. Beberapa asumsi dasar, pertama, media merupakan industri yang berubah dan berkembang yang menciptakan lapangan kerja, barang, dan jasa, serta menghidupkan industri lain yang terkait. Media merupakan industri tersendiri yang memiliki peraturan dan norma-norma yang menghubungkan institusi tersebut dengan masyarakat dan institusi sosial lainnya. Di lain pihak, institusi media diatur oleh masyarakat. Kedua, media merupakan sumber kekuatan, alat kontrol, manajemen, dan inovasi dalam masyarakat yang dapat didayagunakan sebagai pengganti kekuatan atau sumber daya lainnya. Ketiga, 
media merupakan lokasi (forum) yang semakin berperan untuk menampilkan peristiwa-peristiwa kehidupan masyarakat baik yang bertaraf nasional maupun internasional. Keempat, media seringkali berperan sebagai wahana pengembangan kebudayaan bukan saja dalam pengertian pengembangan bentuk seni dan simbol tetapi juga dalam pengertian pengembangan tata cara, mode, gaya hidup, dan normanorma. Kelima, media telah menjadi sumber dominan bukan saja bagi individu untuk memperoleh gambaran dan citra realitas sosial, tetapi juga bagi masyarakat dan kelompok secara kolektif, media menyuguhkan nilai-nilai dan penilaian normatif yang dibaurkan dengan berita dan hiburan (McQuail, 1987).

Konstruksi sosial (social construction) merupakan teori sosiologi kontemporer yang dicetuskan Peter L. Berger dan Thomas Luckmann. Teori ini dimaksudkan sebagai satu kajian teoritis dan sistematis mengenai sosiologi pengetahuan (penalaran teoritis yang sistematis) dan bukan sebagai suatu tinjauan historis mengenai perkembangan disiplin ilmu. Teori ini tidak memokuskan kepada hal-hal semacam tinjauan tokoh, pengaruh dan sejenisnya tetapi lebih menekankan pada tindakan manusia sebagai aktor yang kreatif dari realitas sosialnya (Berger dan Luckmann, 1990).

Dalam paradigma konstruktivis, realitas sosial merupakan konstruksi sosial yang diciptakan oleh individu. Individu adalah manusia bebas yang melakukan hubungan antara manusia yang satu dengan manusia lainnya. Individu menjadi penentu dalam dunia sosial yang dikonstruksi berdasarkan kehendaknya. Individu bukanlah korban fakta sosial, namun sebagai mesin produksi sekaligus reproduksi yang kreatif dalam mengonstruksi dunia sosialnya. Realitas merupakan hasil ciptaan manusia kreatif melalui kekuatan konstruksi sosial terhadap dunia sosial di sekelilingnya. Berger dan Luckmann mengatakan realitas sosial terdiri dari tiga macam. Pertama, realitas objektif terbentuk dari pengalaman di dunia objektif yang berada di luar diri individu dan realita itu dianggap sebagai suatu kenyataan. Kedua, realitas simbolik merupakan ekspresi simbolik dari realitas objektif dalam berbagai bentuk. Ketiga, realitas subjektif merupakan realitas yang terbentuk sebagai proses penyerapan kembali realitas objektif dan simbolik ke dalam individu melalui proses internalisasi (Sudikin, 2002).

Berger menemukan konsep untuk menghubungkan konsep antara yang subjektif dan objektif melalui konsep dialektika yaitu eksternalisasi, objektivasi, dan internalisasi. Eksternalisasi merupakan penyesuaian diri dengan dunia sosiokultural sebagai produk manusia. Objektivasi merupakan interaksi sosial dalam dunia intersubjektif yang dilembagakan atau mengalami proses institusionalisasi. Internalisasi ialah individu mengidentifikasikan diri di tengah lembagalembaga sosial atau organisasi sosial dimana individu tersebut menjadi anggotanya.

Dialektika tersebut berjalan secara simultan. Ada proses menarik keluar (eksternalisasi) sehingga seakan-akan hal itu berada di luar (objektif) kemudian ada proses penarikan kembali ke dalam (internalisasi) sehingga sesuatu yang berada di luar tersebut seakan-akan juga merupakan sesuatu yang berada di dalam diri. Masyarakat adalah produk individu sehingga menjadi kenyataan objektif melalui proses eksternalisasi dan individu juga produk masyarakat melalui proses internalisasi. Pandangan bahwa masyarakat sebagai proses yang berlangsung dalam tiga momen dialektis yang simultan (eksternalisasi, objektivasi, dan internalisasi) serta masalah yang berdimensi kognitif dan normatif, maka yang dinamakan kenyataan sosial adalah suatu konstruksi sosial produk masyarakat sendiri (social constructions of reality) dalam perjalanan sejarahnya di masa lampau, ke masa kini, menuju masa depan (Berger \& Luckmann, 1990). Mengacu pada permasalahan di atas, tulisan ini mengkaji bagaimana framing media online terhadap Islam dan pendidikan karakter. 


\section{METODOLOGI PENELITIAN}

Penelitian ini menggunakan metode penelitian kualitatif. Penelitian kualitatif menekankan sifat realita yang terbangun secara sosial, hubungan erat antara peneliti dengan subjek yang diteliti, dan tekanan situasi yang membentuk penyelidikan (Denzin, 2009). Pendekatan yang digunakan adalah deskriptif, yaitu pemaparan data atas uraian dan penafsiran terhadap pembingkaian berita hasil konstruksi suatu realitas.

Model analisis yang digunakan dalam penelitian ini adalah analisis framing model dari Robert Entman. Framing merupakan proses memilih beberapa elemen dalam melihat realitas dan mengumpulkan narasi yang menunjukkan hubungan diantara mereka untuk mendukung interpretasi. Framing menunjukkan empat fungsi (Entman, 1993, 2004) yaitu problem definition, causal analysis, moral judgment, and remedy promotion (D'Angelo, 2010).

Robert N. Entman merupakan ahli yang menempatkan dasar-dasar bagi analisis framing untuk studi isi media. Konsep framing digunakan untuk menggambarkan proses seleksi dan menonjolkan aspek tertentu dari realitas oleh media. Penyeleksian isu berhubungan dengan proses pemilihan fakta. Dari realitas yang kompleks dan beragam, aspek mana yang akan diseleksi untuk ditampilkan. Ada bagian berita yang dimasukkan (included) dan berita yang dikeluarkan (excluded). Wartawan memilih aspek tertentu dari suatu isu. Penonjolan aspek tertentu dari suatu isu adalah aspek yang berhubungan dengan penulisan fakta (Eriyanto, 2002).

Menurut Entman, framing dalam berita dilakukan dengan empat cara. Pertama, identifikasi masalah (problem identification) yaitu peristiwa dilihat sebagai apa dan dengan nilai positif atau negatif apa. Kedua, identifikasi penyebab masalah (causal interpretation) yaitu siapa yang dianggap penyebab masalah. Ketiga, evaluasi moral (moral evaluation) yaitu penilaian atas penyebab masalah. Keempat, saran penanggulangan masalah (treatment recommendation) yaitu menawarkan suatu cara penanganan masalah dan kadangkala memprediksikan hasilnya (Sobur, 2006).

Gambar 1. Skema Framing Robert Entman (Sobur, 2006)

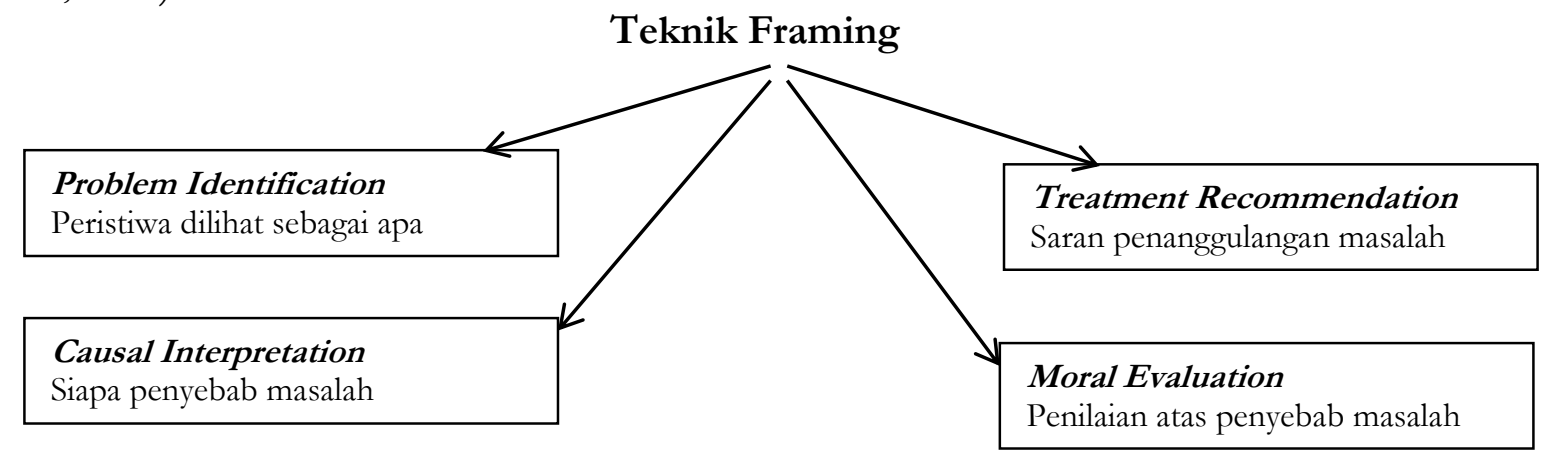


Obyek dalam penelitian ini adalah teks berita Islam dan pendidikan karakter di media online tribunews.com. Pemilihan media online tribunnews.com sebagai obyek penelitian karena media online tersebut merupakan media berskala nasional yang memberitakan Islam dan pendidikan karakter dan merupakan salah satu situs yang paling banyak dikunjungi. Sumber data yang akan digunakan dalam penelitian ini adalah data primer dan data sekunder. Data primer diperoleh melalui pengumpulan dan pendokumentasian teks berita mengenai Islam dan pendidikan karakter di tribunnews.com. Data sekunder diperoleh melalui berbagai sumber seperti buku, jurnal, tesis, dan internet yang dijadikan sebagai bahan acuan penelitian.

\section{PEMBAHASAN}

Islam dan pendidikan karakter merupakan dua hal yang harus menjadi perhatian semua kalangan mengingat Islam dan pendidikan karakter menjadi kunci dalam menghindari tantangan dan permasalahan di era globalisasi. Permasalahan yang akan dihadapi generasi penerus bangsa semakin kompleks. Permasalahan yang ada dapat memicu tindakan dan perilaku yang negatif yang bersumber dari generasi penerus bangsa sendiri sehingga perlu perhatian sejak dini sehingga tidak menimbulkan kerugian bagi pribadi, keluarga, masyarakat, bangsa dan negara.

Persoalan utama atau sumber masalah adalah generasi muda Indonesia berhadapan dengan teknologi informasi yang membuka lebar kesempatan budaya luar memberikan pengaruh bagi generasi penerus bangsa yang cenderung tidak sesuai dengan nilai-nilai Islami dan karakter bangsa Indonesia. Islam dan pendidikan karakter yang diberitakan media menyebabkan opini dan kesan yang muncul dalam informasi sebagai aspek yang bisa menghindarkan tindakan dan perilaku menyimpang generasi penerus bangsa seperti kekerasan dan tawuran, kurang menghargai orang tua, guru, kerabat, teman, serta terjerumus dalam narkoba.

Dalam membingkai berita, tribunnews menegaskan bahwa salah satu jalur yang bisa ditempuh dalam pembentukan karakter yang Islami adalah melalui pendidikan dimana dikembangkan sebuah metode pendidikan yang berbasis $\mathrm{Al}$ Quran yang dinilai mampu membentuk karakter Islami bagi generasi milenial. Pemberitaan tersebut terlihat pada teks berita yang disajikan oleh Tribunnews.com pada tanggal 4 Desember 2017 yang berjudul "Agama Perkuat Karakter Generasi Milenial". Tribunnews.com membingkai pemberitaan mengenai Islam dan pendidikan karakter melalui pemberitaan mengenai pengembangan lembaga pendidikan berbasis Islam dengan level internasional dimana didalamnya terdapat kurikulum pendidikan kepemimpinan. Selain itu bersinergi dengan sekolah-sekolah dari luar Indonesia diantaranya Jepang, Malaysia, Australia, Turki, Singapura. Dalam pemberitaan tersebut, pendiri Jakarta Islamic Boys Boarding School (JIBBS) mengatakan bahwa Rasulullah mengajarkan untuk mendidik anak-anak sesuai dengan zamannya, namun tetap mengedepankan kekuatan dengan karakter keindonesiaan. Dengan membekali kemampuan intelektual dan kepercayaan diri di bidangnya, pendidikan karakter yang Islami yang kuat mampu menghadapi tantangan globalisasi karena dibekali dengan nilai-nilai Qurani yang dicontohkan Nabi Muhammad SAW.

Selanjutnya, teks berita yang disajikan, tribunnews.com pada tanggal 8 Agustus 2017 yang berjudul "Menteri Agama: Pendidikan Karakter Harus Dimulai dari Keluarga" membingkai pemberitaan mengenai pentingnya pendidikan karakter. Dalam pemberitaan, Menteri Agama Republik Indonesia Lukman Hakim Saifuddin mengungkapkan bahwa pendidikan karakter harus diawali dari keluarga melalui keteladanan yang dicontohkan dari lingkungan keluarga. 
Sekolah memiliki peran dalam membentuk pendidikan karakter sehingga sekolah harus memberikan dukungannya agar karakter semakin terbentuk. Pendidikan keluarga dan sekolah perlu disatukan karena pendidikan karakter sangat penting untuk setiap individu memiliki jiwa sosial yang tinggi.

Arti penting pendidikan karakter didukung oleh pemerintah dengan adanya Peraturan Presiden (Perpres) Nomor 87 tentang Penguatan Pendidikan Karakter seperti yang dibingkai tribunnews.com pada tanggal 6 September 2017 yang berjudul "Presiden Jokowi Tandatangani Perpres Penguatan Pendidikan Karakter". Dalam teks berita disampaikan bahwa Presiden Jokowi berharap agar pendidikan karakter di jalur pendidikan seperti sekolah-sekolah umum, pesantren, dan madrasah dapat berjalan dengan baik. Presiden Jokowi mengungkapkan bahwa Perpres penguatan pendidikan karakter mendapat dukungan penuh termasuk para kiai dan pimpinan ormas, serta pimpinan atau perwakilan dari lembaga maupun organisasi sosial keagamaan. Sebelumnya, sejumlah masukan diterima dari perwakilan dari PBNU, AlIrsyad Al-Islamiah, Jam'iyatul Al-Washliyah, Dewan Dakwah Islam Indonesia, Mathla'ul Anwar, Tarbiyah Islamiah, Forum Komunikasi Diniyah Takmiliyah, Rabithah Ma'ahid Islamiyah, MUI, Muhammadiyah, Ikatan Cendekiawan Muslim Indonesia, dan PP Persis. Presiden Jokowi melanjutkan bahwa harapan yang ingin dicapai dengan adanya masukan dari perwakilan masingmasing pimpinan adalah sebuah Perpres yang komprehensif. Kemudian, Perpres tersebut akan segera ditindaklanjuti dengan membuat petunjuk pelaksanaan dan teknis sehingga bisa diterapkan. Perpres ini seperti yang diungkapkan Presiden Jokowi adalah sebagai payung hukum bagi menteri, gubernur, bupati, dan walikota dalam menyiapkan anggaran penguatan pendidikan karakter di madrasah, sekolah dan masyarakat.

Framing media online tribunnews.com terhadap Islam dan pendidikan karakter terkait dukungan penuh terhadap peningkatan pendidikan karakter terus mendapatkan apresiasi melalui berita yang berjudul "Perpres Peningkatan Pendidikan Karakter Solusi Tepat Jawab Masalah Pendidikan" pada tanggal 6 September 2017. Pengurus besar Majelis Dzikir Hubbul Wathon (PB-MD Hubbul Wathon) mengapresiasi komunikasi antara pemerintah dan Pengurus Besar Nahdlatul Ulama (PBNU) serta menilai Perpres Peningkatan Pendidikan Karakter (PPK) sebagai solusi terkait masalah pendidikan di Indonesia. Selain itu, diungkapkan bahwa permasalahan bangsa ke depan dapat diselesaikan dengan kegigihan dan dialog yang disertai dengan semangat mencari jalan keluar.

Pendidikan karakter dengan media semakin membutuhkan perhatian yang serius, lebih lanjut di bingkai tribunnews.com melalui pemberitaan yang berjudul, "Jokowi: Para Guru Hati-hati dan Bijak Gunakan Media Sosial" pada tanggal 2 Desember 2017. Dalam pemberitaan disebutkan bahwa Presiden Jokowi berpesan kepada guru-guru agar bijak menggunakan media sosial. Para guru dihimbau untuk bekerjasama yang baik dengan orangtua serta masyarakat dalam rangka mendidik siswa. Pendidikan karakter disebut sebagai roh pendidikan dan kesadaran kolektif untuk meningkatkan disiplin serta etos kerja.

Perhatian yang serius terhadap agama dan pendidikan karakter semakin didukung oleh pemerintah melalui pemanggilan Presiden terhadap Menteri Agama. Bingkai tribunnews.com ini terlihat melalui teks berita pada tanggal 17 Januari 2017 yang berjudul "Jokowi Panggil Menag Bahas Usulan Pendidikan Agama yang Tidak Konfrontatif'. Para antropolog memberikan usulan kepada Menteri Agama soal pendidikan agama. Pokok masalah yang dibahas adalah pendidikan secara umum. Pendidikan karakter bangsa harus menjadi perhatian semua pihak. Pendidikan terkait jati diri keindonesiaan yang dikenal sebagai masyarakat bangsa yang religius, agamis, 
memperhatikan keragaman, kemajemukan, dan kebhinekaan. Menurut menteri agama, usulan yang disampaikan para antropolog sejalan dengan semangatnya untuk memberikan pendidikan agama yang promotif dan tidak konfrontatif. Semangat yang dimaksud adalah memberikan pendidikan agama yang substantif dengan menyebarluaskannya secara promotif karena penganut agama di Indonesia beragam.

Dukungan terhadap pendidikan karakter kembali dibingkai oleh tribunnews.com pada tanggal 7 Juli 2017 melalui pemberitaannya yang berjudul "Polri Dukung Program Penguatan Pendidikan Karakter Kemdikbud". Dukungan datang dari Polri dalam bentuk apresiasi kebijakan dan langkah Kemdikbud dalam rangka pembangunan karakter. Menurut Polri, penguatan karakter anak adalah langkah tepat untuk membangun generasi yang lebih baik. Harapannya adalah bangsa Indonesia semakin besar, semakin terbuka, dunia tanpa batas dengan generasi muda mendatang jauh lebih baik dan jauh lebih berkarakter. Situasi dan kondisi yang terjadi di Indonesia sangat membutuhkan generasi penerus bangsa.

Selain mendapat dukungan dari berbagai pihak, tribunnews.com membingkai pendidikan dan pembangunan karakter bangsa melalui pemberitaan pada tanggal 5 Oktober 2017 yang berjudul "Pendidikan yang Tepat Berperan dalam Pembangunan Karakter Bangsa". Guru Besar Universitas Islam Negeri (UIN) Syarif Hidayatullah Jakarta menyatakan karakter menjadi krusial di era globalisasi karena orang tua dan sekolah dihadapkan pada kondisi sosial yang bergerak mengikuti logika dan selera pasar. Pertumbuhan anak yang diasuh bersama lingkungan keluarganya, masyarakat budaya yang solid dan homogen mudah diarahkan dan diprediksi. Namun demikian, saat ini terpapar simbol - simbol yang tidak mewakili realitas sejati tapi dianggap sebagai kenyataan. Sebagai contoh, gejala saat ini cenderung memandang karakter seseorang berdasarkan status sosial dan konsumsi barang yang bisa berdampak buruk bagi pendidikan karakter karena identitas dibentuk mengikuti logika pasar. Pilar pendidikan harus diformulasikan ulang dengan mengubah mindset pimpinan sekolah dan guru. Dunia pendidikan terseret masuk dalam persaingan mutu produk seperti di dunia industri sehingga lembaga pendidikan yang tidak bisa menghasilkan alumni yang berkualitas dan kompetitif di lapangan kerja akan menyusut peminatnya. Pendidikan karakter harus membawa bangsa sebagai subjek.

Berbagai upaya dilakukan pemerintah dalam rangka penguatan pendidikan karakter dibingkai dalam tribunnews.com pada tanggal 4 Maret 2017 melalui teks berita yang berjudul "Mendikbud: Gerakan Membaca Wujud Penguatan Pendidikan Karakter". Menteri Pendidikan dan Kebudayaan mengajak anakanak gemar membaca dan memberikan himbauan kepada guru dan orangtua membimbing anak-anak membaca sebagai bentuk penguatan pendidikan karakter.

Pentingnya pendidikan karakter sejak dini kembali dibingkai dalam teks pemberitaan tribunnews.com pada tanggal 7 Juli 2017 yang berjudul "Wakapolri: Karakter Kebangsaan Harus Ditanamkan Sejak Dini”. Wakapolri menyebutkan terjadi pergeseran karakter pada masing-masing anak bangsa. Dalam membangun karakter kebangsaan, perlu adanya peningkatan mutu pendidikan dan peningkatan soliditas dengan melakukan koordinasi antar instansi pemerintahan dan stakeholder. Bagian terpenting adalah perlunya peranan orang tua karena pendidikan moral berasal dari rumah dan lingkungan keluarga.

\section{KESIMPULAN}

Penelitian dengan judul "Islam dan Pendidikan Karakter dalam Framing Media Online" di tribunnews.com, menyimpulkan bahwa tribunnews.com dalam memberitakan Islam dan pendidikan karakter menimbulkan kesan bahwa pembentukan karakter yang Islami bisa 
diwujudkan salah satunya melalui jalur pendidikan yang tepat. Kuatnya pendidikan karakter yang islami bagi generasi bangsa menjadi kunci dalam menghadapi tantangan globalisasi, kemajuan teknologi dan informasi.

Masalah pembentukan dan penguatan pendidikan karakter membutuhkan peran serta dan kerja sama orang tua dan guru melalui pendidikan di rumah, sekolah-sekolah umum, pesantren, dan madrasah. Dukungan dan apresiasi terhadap pendidikan karakter datang melalui pemerintah yang diwujudkan dengan adanya Peraturan Presiden (Perpres) Nomor 87 tentang Penguatan Pendidikan Karakter. Perpres ini mendapat dukungan dari berbagai kalangan karena dapat menjadi solusi terkait masalah pendidikan.

Bingkai tribunnews.com melalui pemberitaanya mengenai pendidikan karakter menunjukkan bahwa kehadiran generasi bangsa sangat dibutuhkan dalam situasi dan kondisi bangsa Indonesia saat ini. Pergeseran karakter pada generasi bangsa dalam bingkai tribunnews.com dapat diselesaikan dengan adanya peningkatan mutu pendidikan dan koordinasi pemerintah dan stakeholder.

\section{DAFTAR PUSTAKA}

Berger, P., \& Thomas, L. (1976). The Social Construction of Reality. England: Penguin Books.

Berger, P., \& Thomas, L. (1990). Tafsir Sosial atas Kenyataan, terj. Hasan Basari dari The Social Construction of Reality: $A$ Treatise in the Sociology of Knowledge. Jakarta: LP3S.

Briggs, A., \& Peter, B. (2006). Sejarah Sosial Media. Jakarta: Yayasan Obor Indonesia.

Bungin, B. (2006). Sosiologi Komunikasi. Jakarta: Kencana Prenadamedia Group.

D'angelo, P., \& Kuypers., J., A. (2010). Doing News Framing Analysis: Empirical and Theoretical Perspectives. New York: Routledge.

Eriyanto. (2002). Analisis Framing. Yogyakarta: LKiS Yogyakarta.

McQuail, D. (1987). Teori Komunikasi Massa. Jakarta: Penerbit Erlangga.

McQuail, D. (2011). Teori Komunikasi Massa. Jakarta: Salemba Humanika.

Musrifah. (2016). Pendidikan Karakter dalam Perspektif Islam. Jurnal Edukasi Islamika: Volume 1, Nomor 1, Desember 2016/1438.

Sobur, A. (2006). Analisis Teks Media. Bandung: PT. Remaja Rosdakarya.

Sudikin, \& Basrowi. (2002). Metode Penelitian Kualitatif Perspektif Mikro. Surabaya: Insan Cendekia Surabaya. 